\title{
Synthesis of Graphene Oxide Enriched Natural Kaolinite Clay and Its Application For Biodiesel Production
}

\author{
Syukri Syukri*, Fadhil Ferdian, Yetria Rilda, Yulia Eka Putri, \\ Mai Efdi, Upita Septiani
}

Department of Chemistry, Faculty of Mathematics and Natural Science, Andalas University, 25163, Indonesia

\begin{abstract}
A heterogeneous catalyst is one type of catalyst which is very effective for biodiesel production; thus, in this study, a novel heterogeneous bifunctional catalyst was prepared by kaolinite clay obtained from Padang of West Sumatera and impregnated with graphene oxide and potassium hydroxide $(\mathrm{KOH})$ for the simultaneous esterification and transesterification reactions of palm oil into biodiesel. For comparison, two other catalysts were also prepared. The first catalyst was the same clay which was heated at $450^{\circ} \mathrm{C}$ for 4 hours, and the second catalyst was the same clay which was impregnated with potassium hydroxide (KOH) only. The three catalysts were characterized using X-Ray Fluorescence (XRF), X-Ray Diffraction (XRD), and Fourier Transform Infra-Red (FTIR). XRF analysis showed that the clay sample's main composition consisted of $54 \%$ silica, $35 \%$ alumina, and $7 \%$ hematite. The XRD analysis results showed that the most dominant crystal composition was quartz, kaolinite, and hematite. The analysis results using FTIR showed a change in intensity and shift in wave numbers indicating a cation exchange. The catalytic activity test was carried out with a ratio of oil and methanol 1:6, catalyst amount $5 \%, 60^{\circ} \mathrm{C}$ reaction temperature, and 4 hours of reaction time. The results showed that the catalytic activity of clays impregnated with graphene oxide and potassium hydroxide was better with a yield of $58 \%$ compared to clays without impregnation and other clays that were only impregnated with $\mathrm{KOH}$ under the yields of $0.8 \%$ and $0.4 \%$, respectively.
\end{abstract}

Keywords: Graphene Oxide, Clay, Transesterification, Biodiesel, Heterogeneous Catalyst.

Article History: Received: $17^{\text {th }}$ Sept 2020; Revised: $17^{\text {th }}$ November 2020; Accepted: $14^{\text {th }}$ December 2020; Availableonline: $6^{\text {th }}$ January 2021

How to Cite This Article: Syukri, S., Ferdian, F., Rilda, Y., Putri, Y.E., Efdi, M. and Septiani, U. (2021). Synthesis of Graphene Oxide Enriched Natural Kaolinite Clay and its Application For Biodiesel Production. Int. Journal of Renewable Energy Development, 10(2), 307-315.

https://doi.org/10.14710/ijred.2021.32915

\section{Introduction}

In recent decades, fossil fuels have been used around 88\% of energy sources and have become an inseparable part of daily human life (Rahmani Vahid \& Haghighi, 2017). Along with the depletion of fuel availability globally and accompanied by increasing world oil prices, it is proof that energy crisis is currently hitting the world. In 2018, primary energy consumption grew $2.9 \%$ in average, it was almost double in its 10-year average of $1.5 \%$ per year, and the fastest since 2010 (Dudley, 2020). The need for crude oil is increasing rapidly in line with the increase in industrialization activities throughout the world. Oil consumption grew by above-average 1.4 million barrels per day $(\mathrm{b} / \mathrm{d})$, or $1.5 \%$. China $(680,000 \mathrm{~b} / \mathrm{d})$ and the US $(500,000 \mathrm{~b} / \mathrm{d})$ were the largest contributors to growth. Coal consumption grew by $1.4 \%$, it was almost double in its 10 year average growth (Dudley, 2020). Economic development has caused a huge energy demand, partly derived from fossil fuels, namely petroleum, coal, and natural gas (Rabie et al., 2018). The demand for large energy sources is not comparable to fossil energy resources whose availability is minimal. The use of fossil energy impacts environmental pollution and globally causes extreme climate change, and has been a concern of people throughout the world in the last few decades (Dang et al., 2013). To overcome this problem, it is necessary to find other alternative energy sources that are more environmentally friendly and renewable resources. Renewable alternative fuels have attracted much attention from researchers worldwide due to fluctuations in oil prices, environmental problems, and limited fossil fuel reserves (Ali et al., 2018).

One of alternative energy sources that can be used is biodiesel. Biodiesel is a mixture of methyl esters, ethyl esters with long-chain fatty acids, mostly produced through the esterification reaction of free fatty acids or transesterification of animal fats, vegetable oils, waste cooking oil, with short-chain alcohols such as methanol or ethanol. The presence of a catalyst helps accelerate the reaction of methyl ester formation by producing a highly reactive anion methoxide, which is resulted from the reaction between the catalyst and methanol.

Transesterification reactions can be carried out with homogeneous catalysts and heterogeneous catalysts (BetMoushoul et al., 2016). However, the use of homogeneous catalysts has several disadvantages, such as the difficulty of separating the catalyst from the product and the

\footnotetext{
* Corresponding author: syukridarajat@sci.unand.ac.id
} 
difficulty of reusing the catalyst and resulting in a large amount of water contamination, which increases production costs (Fadhil et al., 2018). Researchers are currently more focused on applying heterogeneous catalysts for biodiesel production to find suitable solid catalysts for high activity at moderate reaction temperatures (Olutoye \& Hameed, 2013). Heterogeneous catalysts have high-temperature resistance in various operating conditions, facilitate the separation of reaction products, and are easily separated by simple screening (D'Souza et al., 2018). Compared to other heterogeneous materials, natural clay has proven to be more profitable for biodiesel production through transesterification reactions. The versatility and low cost of clay make it a more profitable potential catalyst or catalyst support in various industrial processes (D'Souza et al., 2018). In parallel, some works published in the literature describing the successful use of clay with the addition of other active substances such as HCl (Rabie et al., 2018), Potassium Floride (Alves et al., 2014), barium-modified (Olutoye et al., 2016), and 1benzyl-1H benzimidazole based (Ghiaci et al., 2011) showed good results. Each yielded 87\%; 96\%; $83.38 \%$; and $92 \%$ respectively under different reaction conditions.

Carbon-based catalysts received attention because of their unique surface characteristics (Ali et al., 2018). Graphene oxide represents a new potential type of carbon catalyst due to its unique properties such as high stability, large surface area, and large hydrophilic groups (- $\mathrm{COOH}$ and -OH) (D'Souza et al., 2018). Besides, the carboxyl group at the end of the sheet with the addition of epoxy and hydroxyl functional groups in the basal plane of graphene oxide GO creates a network of strong Lewis and Brønsted acidic properties that can enhance chemical reactions catalyzed by acids (Loy et al., 2019).

In Ali's research (Ali et al., 2018), which modified bentonite with $\mathrm{GO}$ and $\mathrm{NaOH}$, this catalyst showed excellent catalytic performance with free fatty acid conversions of $89.5 \%$ and $98.5 \%$.In other studies, silicon carbide/sodium hydroxide-graphene oxide catalyst provided $96 \%$ transesterification yield and $92 \%$ esterification yield (Loy et al., 2019). It showed that GO was a carbon catalyst with huge opportunities for biodiesel production.

Therefore, this study seeks to find new types of heterogeneous catalysts from raw materials that are inexpensive, environmentally friendly, and have a good catalytic effect in biodiesel production from palm oil. One of the raw materials that can be used is modified clay with graphene oxide support. The clay used in this study was taken from Lubuk Minturun (Padang, Indonesia). Kaolinite clay from Lubuk Minturun was chosen because it had never been studied before. $\mathrm{KOH}$ is used because it shows good catalytic activity in previous studies (Soetaredjo et al., 2011), reaching 90\% biodiesel yield.

\section{Materials and Methods}

\subsection{Materials}

The material used for catalyst preparation was natural kaolinite clay from Lubuk Minturun (Padang, Indonesia), and the material used for modification was graphite powder, Potassium Hydroxide, Sodium Nitrate, Sulfuric
Acid, Potassium Permanganate, Hydrogen Peroxide, and Chloride Acid (all chemicals are obtained from Merck). The samples used for the transesterification study were processed palm oil purchased from the local market, methanol obtained from Merck, and standard fatty acid methyl esters for FAME analysis from Sigma Aldrich (Singapore).

\subsection{Instrumentation}

The instruments used were Philip X-ray Diffraction (XRD) X'pert X-ray Powder Type PW4030/60, X-ray Fluorescence (XRF) PAN analytical Epson 3, Fourier Transform InfraRed (FT-IR), and Gas Chromatography (GC) typed Shimadzu QP 2010.

\subsection{Experimental Procedure}

\subsubsection{Clay Preparation}

Natural kaolinite clay was suspended with distilled water and allowed to settle for 24 hours to reduce impurities. Clay was dried in an oven at $110^{\circ} \mathrm{C}$ for 24 hours and mashed in a mortar, and then sieved with a sieve of 0.250 $\mathrm{mm}$ to prevent clumping and maximize its specific surface area. The resulted powder was stored in a desiccator. This prepared preparation was named O-Clay. Twenty-five grams of $\mathrm{O}$-Clay were calcined at $450^{\circ} \mathrm{C}$ for 4 hours. The sample was named parent clay (P-Clay).

\subsubsection{Preparation of Catalysts Clay Potassium Hydroxide}

An amount of P-Clay was suspended respectively in a 0.5 $\mathrm{M}$ and $0.89 \mathrm{M} \mathrm{KOH}$ solution (with a clay: $\mathrm{KOH}$ ratio $=1: 10$ $\mathrm{w} / \mathrm{v})$, stirred with a magnetic stirrer for one day at room temperature. The solid was separated by filtering with Whatman 41 filter paper and rinsed with distilled water 3 times. The solid was dried at $110^{\circ} \mathrm{C}$ for 3 hours and then crushed and sieved with a $0.250 \mathrm{~mm}$ sieve to obtain the maximum specific surface area. The clay was then calcined at $450^{\circ} \mathrm{C}$ for 4 hours and then labeled with K-Clay $0.5 \mathrm{M}$ and K-Clay $0.89 \mathrm{M}$, respectively.

\subsubsection{Graphene Oxide}

The graphene oxide synthesis process was carried out using a modification of Hummer's method (Ali et al., 2018). 3.5 grams of graphite powder and 4 grams of $\mathrm{NaNO}_{3}$ were dissolved in $120 \mathrm{~mL} \mathrm{98 \%} \mathrm{H}_{2} \mathrm{SO}_{4}$. The addition of 8 grams $\mathrm{KMnO}_{4}$ was carried out gradually into the mixture after the stirring for 2 hours. For 4 hours, the temperature was maintained under $20^{\circ} \mathrm{C}$. The mixture was stirred slowly until it turns into a greenish-black color. The stirring process was continued for 20 hours at $35^{\circ} \mathrm{C}$. After 24 hours of stirring, the mixture changes color to light brown. The mixture was washed with $200 \mathrm{~mL}$ of distilled water and stirred for 1 hour. The mixture was added with $20 \mathrm{~mL}$ of $30 \% \mathrm{H}_{2} \mathrm{O}_{2}$ to remove the excess $\mathrm{KMnO}_{4}$. The resulted mixture was centrifuged and continued with the washing process with $80 \mathrm{~mL} \mathrm{HCl}$ and distilled water. Then ultrasonication was carried out at $50 / 60 \mathrm{kHz}$ ultrasonic waves for 90 minutes to exfoliate graphite oxide to graphene oxide. The sonication mixture was dried at $80^{\circ} \mathrm{C}$ for 12 hours to obtain graphene oxide. 


\subsubsection{Preparation of GO-K-Clay catalyst}

$\mathrm{K}$-Clay $0.89 \mathrm{M}$ was chosen because it is assumed to have a more active sites than K-Clay 0.5 M. K-Clay $0.89 \mathrm{M}$ was mashed and then impregnated with graphene oxide with a ratio of $1: 10$ in an aqueous solution under continuous stirring for 12 hours at $60^{\circ} \mathrm{C}$. After 12 hours, the resulted mixture was dried overnight at $110^{\circ} \mathrm{C}$ and then crushed to be used as a catalyst for biodiesel production. The solid was named GO-K-Clay catalyst.

\subsubsection{Transesterification}

Transesterification of palm oil samples (containing triglycerides) to biodiesel (methyl ester) was carried out in a $250 \mathrm{~mL}$ volume three-neck flask connected with a condenser for the reflux process with a temperature indicator mounted above the hotplate magnetic stirrer. The reaction procedure was as follows: For the reaction stoichiometry, the molar ratio of palm oil and methanol used in this study was 1:6, and the amount of catalyst used was $5 \%$ by weight of palm oil for O-Clay, P-Clay, K-Clay, and GO-K-Clay respectively. Initially, the catalyst and methanol are heated to $50^{\circ} \mathrm{C}$ with continuous stirring in a three-neck flask. Simultaneously, before added to the three-neck flask, $108 \mathrm{~mL}$ of palm oil was previously heated at $105^{\circ} \mathrm{C}$ to remove the water. The temperature was lowered again to $50^{\circ} \mathrm{C}$ so the methanol would not evaporate when mixed with the mixture. The reaction was continued for four hours at $60^{\circ} \mathrm{C}$. At the end of the reaction, the flask was cooled at room temperature, and the catalyst was separated from the product mixture using a vacuum filter. Biodiesel products were separated from glycerol using separating funnels. Biodiesel was washed with hot distilled water $\left(50^{\circ} \mathrm{C}\right)$ with a volume ratio of $1: 1$ and rubbed for 5 minutes to form a white liquid. The mixture was then allowed to stand for a while, so the water separated at the flask's bottom. Biodiesel was heated at temperatures above the boiling point of water $\left(105^{\circ} \mathrm{C}\right)$ until there were no more water bubbles, then the predicted products containing methyl esters were filtered with Whatman paper. The main chemical components in the product were analyzed using GC-MS and Viscosity (ASTM D-445-10). The content of FAME in the biodiesel produced was analyzed by GC using a DBwax capillary column (Agilent JW Scientific) and Flame Ionization Detector (FID) as in (Suryaputra et al., 2013). The injector temperature was $250^{\circ} \mathrm{C}$ at the splitless condition, and FID was set at $300^{\circ} \mathrm{C}$. The yield was calculated in Equation (1).

$$
\text { BD Yield }(\%)=\frac{\text { Weight of Pure Methyl Esther }}{\text { Total Weight of Oil Used }}
$$

\section{Results And Discussion}

\subsection{Graphene Oxide}

Graphene Oxide (GO) can be synthesized using several Hummer modification methods suggested by Taufantri (Taufantri et al., 2016), Rafitasari (Rafitasari et al., 2016), and Ali (Ali et al., 2018). GO synthesis is carried out by reacting graphite powder, $\mathrm{KMnO}_{4}$, and $\mathrm{NaNO}_{3}$ into a concentrated $\mathrm{H}_{2} \mathrm{SO}_{4}$ solution (98\%) in an ice bath with a temperature not exceeding $20^{\circ} \mathrm{C}$ to produce an optimal oxidation reaction and avoid the explosion due to the formation of carboxyl compounds that can occur. This oxidation process aims to obtain oxidized graphite and produce intercalated graphite. This intercalation will increase the distance between the graphene layers and weaken the layers' interaction (Hidayat et al., 2019). Several functional groups such as phenol groups, epoxy groups, ketone groups, carboxyl groups, and carbonyl groups form on carbon (Shao et al., 2012). This functional group causes the material to be very hydrophilic (Gao, 2012). The addition of strong acids and sufficient reaction time in the GO synthesis process aims to homogenize and accelerate breaking bonds between the layers in carbon. It is because graphene, which has a strong bond structure, is layered to form graphite. In a graphite structure, each carbon atom forms a covalent bond with three other carbon atoms forming a hexagonal arrangement with a layered structure like a stack of cards (Simarmata, 2018).

Reactions that occur during the oxidation process can be expressed by equations 2 and 3. This oxidation process can only take place under acidic conditions. In this study, $\mathrm{H}_{2} \mathrm{SO}_{4}$ was used as a source of acid. The active species which reacted was dimanganese heptoxide. Bimetallic heptoxide was much more reactive than nonmetallic tetraoxide. After this stage, the starting material, graphite powder, has turned into graphite oxide (Johansen, 2014).

$$
\begin{aligned}
& \mathrm{KMnO}_{4}+3 \mathrm{H}_{2} \mathrm{SO}_{4} \rightarrow \mathrm{K}^{+}+\mathrm{MnO}_{3}{ }^{+}+\mathrm{H}_{3} \mathrm{O}^{+}+3 \mathrm{HSO}_{4} \\
& \mathrm{MnO}_{3}{ }^{+}+\mathrm{MnO}_{4}^{-} \rightarrow \mathrm{Mn}_{2} \mathrm{O}_{7}
\end{aligned}
$$

The oxidation reaction produces a greenish-black mixture which indicates the oxidation process (Kusrini, 2018). In addition to perfecting the intercalation of graphite and sulfuric acid, the addition of $\mathrm{KMnO}_{4}$ also helps in graphite oxidation. Two reactions of graphite bisulfate formation and oxidation take place simultaneously. Potassium permanganate is one of the strong oxidizing agents, especially in an acidic atmosphere. The penetration of $\mathrm{KMnO}_{4}$ into the graphite layer is very effective for oxidizing graphite (Hidayat et al., 2019).

The addition of distilled water causes a change in color to be dark brown. At the end of the process, the addition of $\mathrm{H}_{2} \mathrm{O}_{2}$ is carried out as an oxidizing agent and helped break bonds into one atomic layer. $\mathrm{H}_{2} \mathrm{O}_{2}$ playes a role in reducing permanganate residues after the reaction and stopping the reaction (Hidayat et al., 2019). The addition of $\mathrm{H}_{2} \mathrm{O}_{2}$ causes a change in the color of the mixture to be yellow with a slight green tint that indicates that there is still unreacted graphite. The reactions that occur when adding $\mathrm{KMnO}_{4}$ and $\mathrm{H}_{2} \mathrm{O}_{2}$ are as follows:

$$
\begin{aligned}
& \mathrm{KMnO}_{4}+3 \mathrm{C}+\mathrm{H}_{2} \mathrm{O} \rightarrow 4 \mathrm{MnO}_{2}+\mathrm{CO}_{3}{ }^{2-}+2 \mathrm{HCO}_{3}- \\
& \mathrm{MnO}_{2} \stackrel{\mathrm{MnO}_{2}}{\rightarrow} \mathrm{O}_{2}+2 \mathrm{H}_{2} \mathrm{O}
\end{aligned}
$$

Washing with $\mathrm{HCl}$ and distilled water aims to remove the oxidizing agent and stabilize the acidity of the sulfate ions, $\mathrm{KMnO}_{4}, \mathrm{H}_{2} \mathrm{O}_{2}$, and compounds which are contained in the GO solution. Also, washing with distilled water helps to peel the graphene oxide sheet to produce a stable suspension in $\mathrm{H}_{2} \mathrm{O}$, which was characterized by the blackening of the mixture (Johansen, 2014). GO is obtained from exfoliating graphite oxide using the sonication process. This peeling can occur due to the presence of ultrasonic waves (Hidayat et al., 2019). 


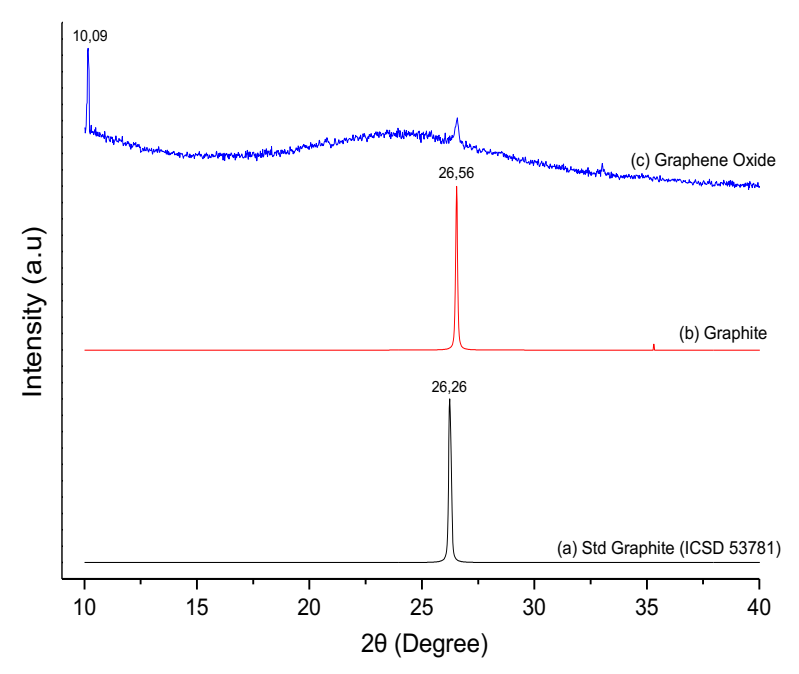

Fig. 1. XRD diffractogram: (a) standard graphite (ICSD 53781), (b) graphite, (c) GO.

Ultrasonic waves have a frequency range of more than $20,000 \mathrm{~Hz}$ and include mechanical waves, so the process of peeling graphene oxide from graphite oxide is carried out mechanically. The peeling process starts with the interaction between graphite oxide due to interaction with ultrasonic waves, which causes shear forces on graphite oxide. The pressure difference caused the cavitation process during sonication, which causes the initiation of the graphite oxide peeling process into graphene oxide (Hidayat et al., 2019). Black GO powder was obtained by drying sediment at $80^{\circ} \mathrm{C}$.

$\mathrm{XRD}$ analysis is carried out to determine the crystal structure and the changes that occur due to the modification process. Fig. 1 shows the XRD pattern of GO generated by the Hummers method. Fig.1(a) shows the XRD pattern of graphite, while Fig.1(c) shows the XRD pattern of GO which was resulted from synthesis. Fig. 1(a) shows that graphite has a diffraction peak at $2 \theta=26.56^{\circ}$ with d-spacing $3.36 \AA$. Fig. 1. (b) shows the appearance of a new peak at $2 \theta=10.09^{\circ}$ with d-spacing $8.76 \AA$, which is a typical peak of GO. This peak affirms what has been reported by many previous researchers that the peak of diffraction GO lies at $2 \theta=10^{\circ}$ (Ali et al., 2018), $2 \theta=10.7^{\circ}$ (D'Souza et al., 2018), and $2 \theta=10.1^{\circ}$ (Waktu et al., 2013). However, in Fig. 1. (c), graphite peaks are still visible at $2 \theta=26.25^{\circ}-26.75^{\circ}$. It could be due to graphite presence, which does not react and become impurities on the synthesized GO. A change in the XRD angle pattern that shifts to the left indicates a decrease in GO's crystallinity. Changes in d-spacing from $3.36 \AA$ on graphite to $8.76 \AA$ on GO are caused by the formation of carbonyl groups, ketone groups, epoxy groups, carboxyl groups, and phenol groups. The addition of water and oxygen molecules between layers also causes GO to have d-spacing wider (Taufantri et al., 2016; Waktu et al., 2013).

Some typical absorption which is found on GO appears in the FTIR spectra as shown by Fig. 2. The most characteristic spectra feature is the intense band of $-\mathrm{OH}$ stretching vibration at $2800-3450 \mathrm{~cm}-1$, the hydroxyl functional groups, and absorbed water molecules. The absorption band at $1700.92 \mathrm{~cm}^{-1}$ and $1890 \mathrm{~cm}^{-1}$ is the vibration of the $\mathrm{C}=\mathrm{O}$ strain of the carbonyl and carboxyl groups at the GO layer edge.

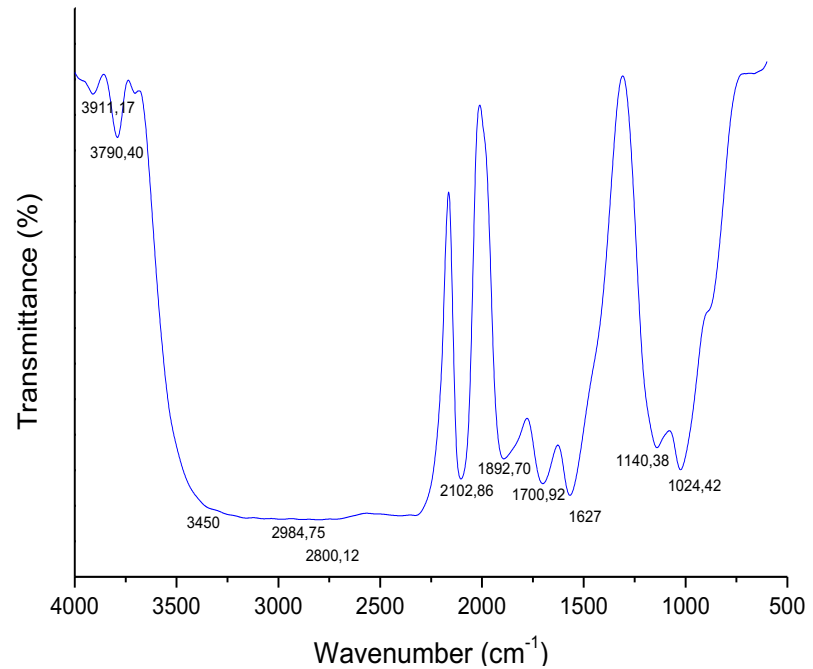

Fig. 2. FTIR Spectra GO

The absorption bands at $1140 \mathrm{~cm}^{-1}$ and $2984 \mathrm{~cm}^{-1}$ are, respectively, C-O-C strain vibrations and $\mathrm{C}-\mathrm{H}$ strain vibrations. The absorption bands $1627 \mathrm{~cm}^{-1}$ and $2102 \mathrm{~cm}^{-1}$ are the aromatic vibrations of the $\mathrm{C}=\mathrm{C}$ strain. The absorption band at $1024 \mathrm{~cm}^{-1}$ is a vibration C-O strain. C$\mathrm{O}$ group indicates the successful oxidation of graphite and indicates that GO has hydrophilic properties (Amri et al., 2018; Cheng et al., 2017; Gaidukevic et al., 2018; Narayanan et al., 2019). Graphite oxide is highly hydrophilic and quickly hydrates when exposed to moisture or immersion in water, resulting in a marked increase in inter-planar distance (up to $1.2 \mathrm{~nm}$ in the saturated state). Additional water also flows into the interlayer space due to induced high pressure (Talyzin et al., 2008).

\subsection{Characteristics of Clay Before and After Modification}

Natural Clay (O-Clay) is yellowish-brown and belonged to the acid soil group with a $\mathrm{pH}$ of 5 . After heating to a temperature of $450^{\circ} \mathrm{C}$, the color of O-Clay changed to be reddish-brown due to dehydration and decomposition of organic components in clay which is accompanied by an increase in $\mathrm{pH}$ due to partial release of $\mathrm{H}^{+}$ions in O-Clay (Syukri et al., 2020). Besides, when the O-Clay sample is heated to this temperature, the $\mathrm{Fe}_{2} \mathrm{O}_{3} \cdot \mathrm{H}_{2} \mathrm{O}$ (goethite) which is contained in theory would change to $\mathrm{Fe}_{2} \mathrm{O}_{3}$ (hematite) (Thomas, 2010).

Modification of clay by heating, impregnation with $\mathrm{KOH}$, and impregnation with GO aims to maximize the catalyst's active sites. This modification will add active groups to the catalyst for the transesterification reaction, the more active sitess on the catalyst, the higher the catalytic activity.

When the clay is modified with $\mathrm{KOH}$, the color changes to be light brown with the assumption that during the impregnation process, the $\mathrm{KOH}$ molecule fills the pores available in the clay, and $\mathrm{K}^{+}$ions occupy a position between the clay crystal layers and replace some $\mathrm{H}^{+}$ions naturally found in clay structures (Syukri et al., 2020). The presence of $\mathrm{KOH}$ molecules on the surface of clay particles, and the surface of pores in clay particles, and 
some $\mathrm{KOH}$ may be converted to $\mathrm{K}_{2} \mathrm{O}$ during calcination (Soetaredjo et al., 2011). Not all potassium mixed with clay is as $\mathrm{K}^{+}$, which replaces the $\mathrm{H}^{+}$position, but some other potassium mixed in clay remains as $\mathrm{KOH}$. It is evidenced by the increase of $\mathrm{pH}$ from 5 to 7 , which will later be shown in XRF and XRD analysis.

When the clay is modified with $\mathrm{KOH}$ and GO, the clay's $\mathrm{pH}$ rises to 8 , and the color changes to be dark brown. The increase in $\mathrm{pH}$ is because the $\mathrm{KOH}$ used has a higher concentration, which is $0.89 \mathrm{M}$. The higher concentration of $\mathrm{KOH}$ used causes the $\mathrm{pH}$ to rise as a result of some $\mathrm{KOH}$ molecules mixed in the clay remained as $\mathrm{KOH}$, but GO maintains the $\mathrm{pH}$ that does not significantly increase because the synthesized GO has a $\mathrm{pH}$ of 3 . GO also contains the Brønsted acidic site along with the carboxyl, hydroxyl, and epoxide functional groups. The change in color to be dark brown is due to GO being a carbon allotrope with black. As a result, when the clay is impregnated with GO, the color changes to be darker. This clay modification with $\mathrm{KOH}$ and GO causes the presence of acidic (GO) and basic (KOH-Clay) sites on the catalyst surface.

\subsection{XRF Clay Analysis Before and After Modification}

$\mathrm{XRF}$ analysis is used to determine the content of the elements contained in clay samples. The XRF results (Table 1) shows that the most dominant composition is $\mathrm{SiO}_{2} 54 \%, \mathrm{Al}_{2} \mathrm{O}_{3} 35 \%$, and $\mathrm{Fe}_{2} \mathrm{O}_{3} 7 \%$. The rest is metal oxides of magnesium, calcium, titanium, nickel, vanadium, potassium, chromium, manganese, copper, zinc, gallium, yttrium, zirconium, silver, europium, lead, oxide non-metals from sulfur trioxide, and phosphorus pentaoxide which is about $1.9 \%$. When heated at $450^{\circ} \mathrm{C}(\mathrm{P}$ Clay), O-Clay samples show significant changes in the composition of oxides such as $\mathrm{Fe}_{2} \mathrm{O}_{3}$, which increases from $7.1 \%$ to be $9.1 \%$ following previous estimates which changes the clay's color to be reddish-brown. Theoretically, some organic compounds can detach from clay, starting from $100^{\circ} \mathrm{C}$ (Thomas, 2010).

Impregnation of $\mathrm{P}$-Clay with $\mathrm{KOH}$ results in an increase in $\mathrm{K}_{2} \mathrm{O}$ levels from $0.06 \%$ to $7.05 \%$, indicating the success of $\mathrm{KOH}$ impregnation in clay. Impregnation of $\mathrm{KOH}$ causes a decrease in $\mathrm{SiO}_{2}$ and $\mathrm{Al}_{2} \mathrm{O}_{3}$ levels and loss of $\mathrm{SO}_{3}, \mathrm{CaO}$, and $\mathrm{Ni}$. This is assumed that it is caused by cation exchange, and the calcination process can cause damage to crystal structure and dilution of other mineral phases upon addition of $\mathrm{K}^{+}$ion. Impregnation of P-Clay with $\mathrm{KOH}$ and $\mathrm{GO}$ increased $\mathrm{K}_{2} \mathrm{O}$ levels from $0.063 \%$ to $11.388 \%$ because the $\mathrm{KOH}$ concentration used is much higher than K-Clay at $0.89 \mathrm{M}$.

\subsection{XRD Clay Analysis Before and After Modification}

XRD analysis (Fig. 3) is used to determine the mineral content in clay, whether in the form of kaolinite, quartz, hematite, cristobalite, gibbsite, and halloysite, and montmorillonite. The results of characterization using XRD (Fig. 3) shows that the O-Clay sample contains $\mathrm{Al}_{2} \mathrm{O}_{3} .2 \mathrm{SiO}_{2} .2 \mathrm{H}_{2} \mathrm{O}(\mathrm{K}), \mathrm{SiO}_{2}(\mathrm{Q})$ quartz, and $\mathrm{Fe}_{2} \mathrm{O}_{3}(\mathrm{H})$ hematite. There are also peaks of cristobalite $\mathrm{SiO}_{2}$ and gibbsite $\mathrm{Al}(\mathrm{OH})_{3}$ but not too dominant.

Heating O-Clay to $450^{\circ} \mathrm{C}$ (P-Clay) does not cause too significant changes in the diffraction pattern. A slight shift of the diffraction pattern to the right indicates that the change in crystallinity increases. The hematite peak becomes clearer after heating due to a change in $\mathrm{Fe}_{2} \mathrm{O}_{3} \cdot \mathrm{H}_{2} \mathrm{O}$ (goethite) to $\mathrm{Fe}_{2} \mathrm{O}_{3}$ (hematite).

The clay impregnation process with $\mathrm{KOH}$ does not significantly change in K-Clay, but a new peak emerges from the $\mathrm{K}_{2} \mathrm{O}$ phase. During calcination, potassium hydroxide is converted to $\mathrm{K}_{2} \mathrm{O}$, as shown in the XRD pattern. Reflections at around $2 \theta=31^{\circ}, 39^{\circ}, 51^{\circ}, 55^{\circ}$, and $62^{\circ}$ are included in the $\mathrm{K}_{2} \mathrm{O}$ phase. The XRD pattern of $\mathrm{K}_{2} \mathrm{O}$ has a small intensity, so it was not so clearly visible. It could be caused due to the addition of $\mathrm{KOH}$ which was not too much, with the ratio of 1:10 (KOH: Clay). From previous studies (Ali et al., 2018) which modified bentonite with $\mathrm{KOH}$, it shows that the effect of adding $\mathrm{KOH}$ from $5 \%$ ( $\mathrm{KOH} /$ bentonite 1:20) to be $25 \%(\mathrm{KOH} /$ bentonite 1: 4), causes the $\mathrm{K}_{2} \mathrm{O}$ peak to have a higher intensity. The formation of $\mathrm{K}_{2} \mathrm{O}$ is also a strong indication that $\mathrm{KOH}$ is not well dispersed on clay's surface or structure (Soetaredjo et al., 2011). It also causes the catalyst's pH to increase from 6 (P-Clay) to 7 (K-Clay).

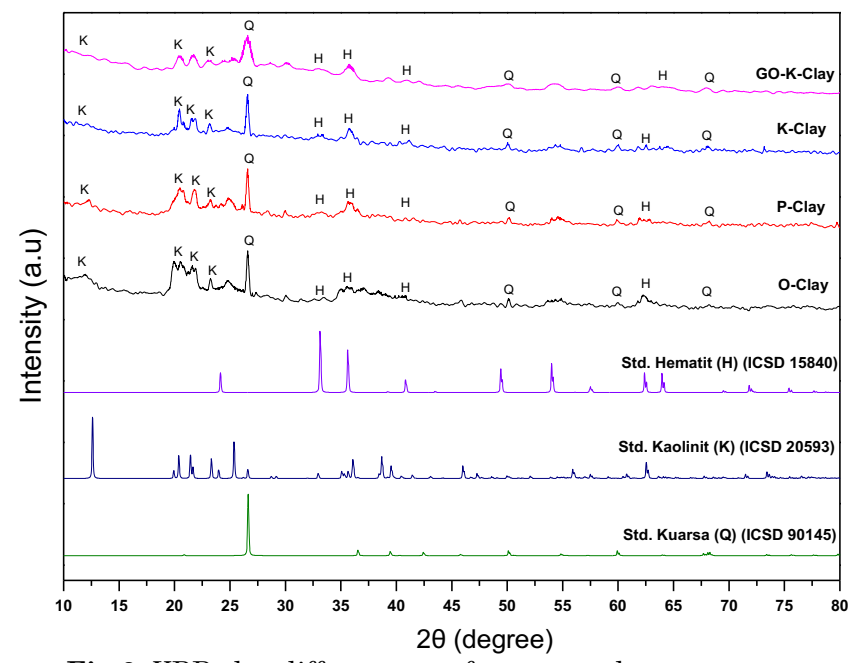

Fig 3. XRD clay diffractogram from several treatments.

Table 1.

Clay composition before and after modification

\begin{tabular}{|c|c|c|c|c|}
\hline Composition & O-Clay & P-Clay & K-Clay & GO-K-Clay \\
\hline${ }^{*} \mathrm{Al}_{2} \mathrm{O}_{3}(\%)$ & 35.782 & 32.755 & 26.342 & 28.262 \\
\hline${ }^{*} \mathrm{SiO}_{2}(\%)$ & 54.531 & 54.159 & 46.802 & 48.169 \\
\hline${ }^{*} \mathrm{~K}_{2} \mathrm{O}(\%)$ & 0.052 & 0.063 & 7.055 & 11.388 \\
\hline${ }^{*} \mathrm{Fe}_{2} \mathrm{O}_{3}(\%)$ & 7.106 & 9.197 & 11.206 & 8.477 \\
\hline Others & \multicolumn{4}{|c|}{$1.9 \%$} \\
\hline
\end{tabular}


No prominent GO peaks are observed on the GO-K-Clay catalyst at $2 \theta=10.09^{\circ}$, indicating GO's homogeneous distribution in porous clay structures. However, there is a widening of the diffraction pattern observed at $2 \theta=26^{\circ}$. $27^{\circ}$, a diffraction pattern of graphite-reinforced with quartz. Reflections around $2 \theta=39^{\circ}, 51^{\circ}, 55^{\circ}$, and $62^{\circ}$ indicate the presence of $\mathrm{K}_{2} \mathrm{O}$ crystals formed during GO$\mathrm{K}$-Clay calcination. The peak of $\mathrm{K}_{2} \mathrm{O}$ diffraction has a slightly higher intensity than the K-Clay catalyst due to the $\mathrm{KOH}$ concentration used was much higher, namely $0.89 \mathrm{M}$.

\subsection{FTIR Clay Analysis Before and After Modification}

Infrared spectroscopy was used to determine what functional groups were found in clay. Each absorption band shows vibrations specific to the related functional group. Fig. 4. showed the results of the FTIR analysis of clay with various treatments.

The FTIR spectrum of O-Clay and P-Clay is shown in Fig.s 4.(a) and 4.(b). The absorption band that appears in the range $3000-4000 \mathrm{~cm}^{-1}$ is the $\mathrm{OH}$ group stretching vibration. The absorption bands at 3623 and $3630 \mathrm{~cm}^{-1}$ for $\mathrm{O}$-Clay and P-Clay are vibrations of the inner -OH group stretching between tetrahedral and octahedral sheets. It is very close to $3620 \mathrm{~cm}^{-1}$, which is previously discovered by Zhang (Zhang et al., 2016). The absorption band at 3600 $\mathrm{cm}^{-1}$ and $900-920 \mathrm{~cm}^{-1}$ shows the stretching vibration of $\mathrm{OH}$ from $\mathrm{Al}(\mathrm{Mg})-\mathrm{OH}$. Simultaneously, the absorption around $3390 \mathrm{~cm}^{-1}$ on O-Clay is a stretching vibration of $\mathrm{H}_{2} \mathrm{O}$, which was strengthened by the appearance of absorption bands at $1600-1700 \mathrm{~cm}^{-1}$ and $2000-2200 \mathrm{~cm}^{-1}$ is bending vibrations of water molecules. When heating to $450^{\circ} \mathrm{C}$, this absorption band decreases in intensity in the P-Clay spectra due to water molecules' loss (Rahayu, 2017; Zhang et al., 2016). There is an absorption band with sharp intensity in $910-1040 \mathrm{~cm}^{-1}$, which is strengthened by absorption at $670-690 \mathrm{~cm}^{-1}$, which is the vibration of Si-O (Schroeder, 2002).

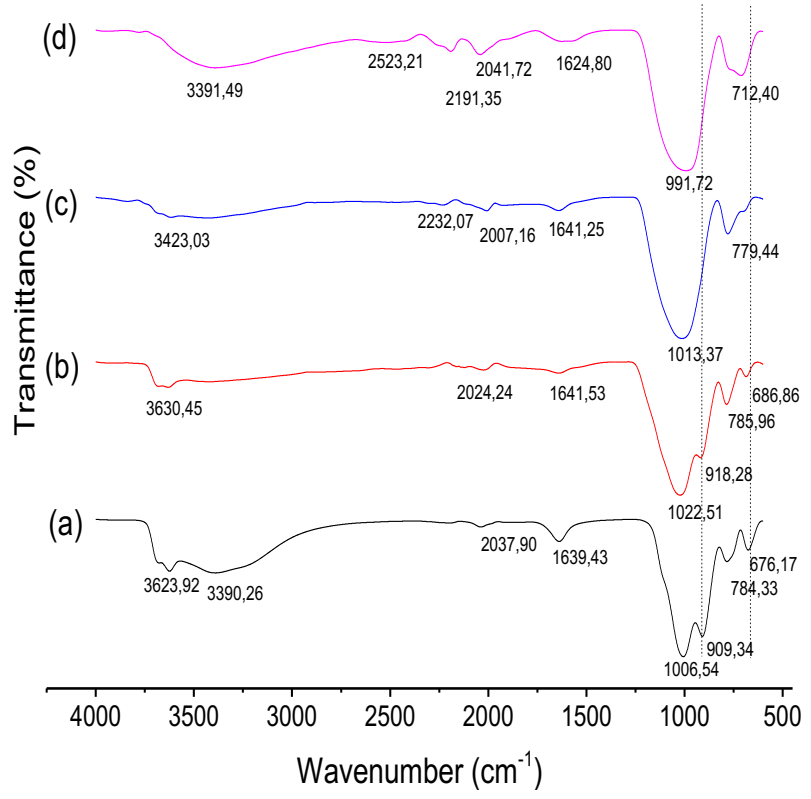

Fig. 4. FTIR clay spectra with four treatments: (a) O-Clay, (b) P-Clay, (c) K-Clay, (d) GO-K-Clay
It is also supported by the wave number absorption around 700-795 $\mathrm{cm}^{-1}$, which is the quartz $\mathrm{Si}-\mathrm{O}-\mathrm{Si}$ bending vibration. This data affirms the previous XRF and XRD analysis, which shows the quartz high content and kaolinite in clay (Costanzo, 2001).

FTIR analysis is also carried out for clay modified with the addition of $\mathrm{KOH}$ and GO. In general, all the typical vibrations of clay occur in all four samples (O-Clay, PClay, K-Clay, and GO-K-Clay). There is no significant difference after modification. In K-Clay (Fig. 4.(c)), a new functional group appeares at the $3423 \mathrm{~cm}^{-1}$, which is a stretching vibration of Al-O-K (Soetaredjo et al., 2011). According to Xie and Haitou, on a completely hydroxylated alumina surface, $\mathrm{K}^{+}$ions can replace protons from isolated hydroxy groups to form $\mathrm{Al}-\mathrm{O}-\mathrm{K}$ groups during the activation process (Xie \& $\mathrm{Li}, 2006$ ).

In Fig. 4.(d), GO-K-Clay shows the absorption band at $712.40 \mathrm{~cm}^{-1}$, a vibration from Si-C indicating that GO is distributed on clay. The absorption band at $1624.80 \mathrm{~cm}^{-1}$ is the vibration of $\mathrm{C}=\mathrm{O}$. The relatively broad and intense absorption band at the $3391.49 \mathrm{~cm}^{-1}$ are the $\mathrm{OH}$ group vibration from carboxyl or water absorbed during the impregnation process. FT-IR results show that the $-\mathrm{OH}$ and $\mathrm{C}=\mathrm{O}$ bands are quite intense in the spectra, which implies the strong acidic sites and basic sites of GO and $\mathrm{KOH}$, which provide good bi-functional catalyst performance (Loy et al., 2019).

The results of FTIR analysis shows that there is a change in intensity and a shift in the wavenumber, which indicates that cation exchange had occurred. It is evidenced by the loss or reduction in Si-O absorption intensity at $900 \mathrm{~cm}^{-1}$, after impregnation with $\mathrm{KOH}$ and GO. This shift can be caused by the appearance of new absorption bands at $712 \mathrm{~cm}^{-1}$ and $3423 \mathrm{~cm}^{-1}$ on the GO-KClay and K-Clay catalysts, which are vibrations from Si-C and $\mathrm{Al}-\mathrm{O}-\mathrm{K}$, respectively. This reduction in Si-O vibrational intensity is in line with the decrease in $\mathrm{SiO}_{2}$ levels, as confirmed by XRF data.

\subsection{Clay Catalytic Activity Before and After Modification}

The content of free fatty acids (Free Fatty Acid, FFA) of vegetable oil (palm oil) used has been tested in previous studies, amounting to $0.45 \%$. Clay, which is modified by several treatments and is used as a solid catalyst for transesterification reaction. This clay catalyst serves to form methoxide anions from methanol, which is highly reactive, attacking the $\mathrm{C}$ carbonyl atom on the triglycerides in palm oil to produce methyl esters (biodiesel). Meanwhile, methanol acts as a reactant and a solvent, which will produce the active species methoxide anion when added to the catalyst.

Fig. 5 shows the catalytic test results of each catalyst. From the test results, it appears that methyl esters were formed on all catalysts with varying yields. O-Clay and PClay exhibit very little catalytic activity of $0.83 \%$ and $0.61 \%$, respectively. It is because the unmodified clay has a lower active sites compared to other impurity components. These impurity components covers the clay pores and inhibits reactant molecules adsorption to the catalyst active sites through the pores. The previous study (Alves et al., 2014) also shows that natural clay catalytic activity is only $3.3 \%$. 


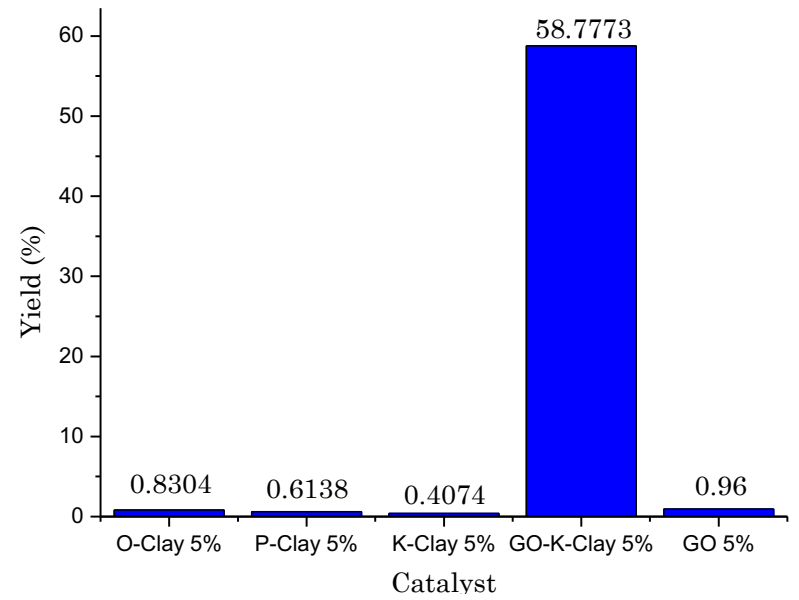

Fig. 5. Clay catalytic test results on transesterification of vegetable oils

When the clay is impregnated with $\mathrm{KOH}$ (K-Clay), it does not show significant catalytic activity than O-Clay and P-Clay. It can be due to the appearance of the Al-O-K phase at wave number $3423 \mathrm{~cm}^{-1}$. This Al-O-K phase has lower catalytic and basic activity than the $\mathrm{K}_{2} \mathrm{O}$ phase. When Al-O-K compounds are formed with high concentrations, the catalyst's catalytic activity becomes lower, which results in a decrease in biodiesel yield (Soetaredjo et al., 2011). It can also be caused due to an imbalance of reactant adsorption and desorption of the final product. Biodiesel production with heterogeneous catalysts involve three reaction steps; adsorption of reactants on the catalyst, chemical reactions on the catalyst active sites, and the final product desorption. First, adsorption of reactants on the active sitess of acids and bases results in carbocation and oxygen anions from FFA and methanol molecules, respectively. The second step, the nucleophilic reaction of the carbocation and the oxygen anion, occurs in the hydroxyl group of methanol and the carbonyl group of triglycerides simultaneously facilitates esterification and transesterification (Ali et al., 2018).

Also, the amount of catalyst added (5\%) can also affect FAME levels. The addition of an enormous catalyst causes the formation of a thicker phase (emulsion) and limiting the mass transfer of components to the catalyst active surface, which causes saturation of the catalytic system with the maximum amount of active sites and diffusion during the reaction. This effect reduces FAME results as observed with higher catalyst loading (Ali et al., 2018; Olutoye \& Hameed, 2013).
The GO-K-Clay catalyst shows better catalytic activity than the O-Clay, P-Clay, and K-Clay catalysts, which reaches 58.7\%. GO contains Brønsted acidic sites along with carboxyl, hydroxyl, and epoxide groups. It is important to note that the Brønsted acidic side plays a vital role in the esterification of oil FFA content. $\mathrm{KOH}$ serves to provide an basic sites of the catalyst that is thought to originate from the formation of $\mathrm{K}_{2} \mathrm{O}$. The active sites of bases with weak strength plays a crucial role in the transesterification of vegetable oils. In Ali's study (Ali et al., 2018), there is a weak strength of the active sites of Brønsted acidic in GO-NaOH-bentonite with a total acidity higher of $0.20 \mathrm{mmol} \mathrm{g}^{-1}$ than $\mathrm{NaOH}$-bentonite 0.14 mmol g-1 proven by (TPD)-NH3 analysis with one major distinct desorption peaks of ammonia resulted at approximately $50-210^{\circ} \mathrm{C}$ revealing that both catalysts has weak acidic sites below $270{ }^{\circ} \mathrm{C}$. The active sites of Brønsted acidic is high because the presence of GO is sufficient for FFA esterification, which makes GO-NaOHbentonite a promising catalyst for esterification transesterification with a biodiesel yield of $98.5 \%$ (Ali et al., 2018).

From previous studies (Ali et al., 2018), it is explained that GO plays a dual function: the first is increasing pore size and, as a result, increasing mass transfer; the second is increasing the weak strength of the active sites of Brønsted acidic in $\mathrm{GO}-\mathrm{NaOH}$-bentonite for esterification of FFA. It is evidenced by the analysis of $\mathrm{N}_{2}$ physisorption, which shows an increased uptake pressure at $\mathrm{P} / \mathrm{P0}=$ $0.9-1.0$, which is an indication of mesoporosity that is obtained due to inter-particles pores (Ali et al., 2018). It is hoped that the reaction mechanism for simultaneous esterification and transesterification is similar to the separate esterification and transesterification reaction. However, the presence of acidic sites (GO) and basic sites (K-Clay) on the surface of the catalyst (GO-K-Clay) succeeds in converting FFA and triglycerides into FAME simultaneously with a little soap formation. Blocking saponification can be attributed to the stronger FFA combining ability to be adsorbed on the acidic sites (GO) in the GO-K-Clay composite (Ali et al., 2018).

\subsection{Physical Properties of Synthesis of Biodiesel}

Biodiesel produced from vegetable oil using O-Clay, PClay, K-Clay, and GO-K-Clay catalysts is characterized for its physical and chemical properties. Table 2 shows the density and viscosity of synthesized biodiesel and is accompanied with data by the Indonesian National Standard (SNI) number 7182: 2015 for biodiesel. SNI standard for the range of viscosity value is $2.3-6.0$.

Table 2.

Physical Properties of Synthesis of Biodiesel

\begin{tabular}{ccccccc}
\hline Parameters & \multicolumn{5}{c}{ Catalyst Type } & SNI \\
\cline { 2 - 6 } Standard \\
\hline Density $@ 40^{\circ} \mathrm{C}(\mathrm{g} / \mathrm{mL})$ & 0.8553 & 0.8657 & 0.8677 & 0.8543 & 0.8749 & $0.85-0.89$ \\
Viscosity $@ 40^{\circ} \mathrm{C}\left(\mathrm{mm}^{2} / \mathrm{s}\right)$ & 26.81 & 40.16 & 34.70 & 29.23 & - & $2.3-6.0$ \\
\hline
\end{tabular}


$\mathrm{mm}^{2} / \mathrm{s}$ and SNI standard for the range of biodiesel density value is $0.85-0.89 \mathrm{~g} / \mathrm{mL}$. Kinematic viscosity and density are two crucial parameters required by biodiesel and diesel fuel standards because they are important keys for diesel engines.

The density of biodiesel synthesis result is included in the range of SNI standards for biodiesel. The lowest density is owned by O-Clay at $0.8553 \mathrm{~g} / \mathrm{mL}$, while GO owns the highest at $0.8749 \mathrm{~g} / \mathrm{mL}$. Density is an important factor during processing and burning fuel because fuel represents extra weight in vesicles (Rabie et al., 2018). The higher density will lead to greater fuel consumption. The density affects the biodiesel mass injected into the combustion chamber and, thus, the air-fuel ratio. The injection pumps the biodiesel by volume rather than by mass, and denser biodiesel contains greater mass in the same volume. Thus, biodiesel density value changes will affect the engine output power due to differences in the mass of injected biodiesel (Refaat, 2009).

The viscosity of biodiesel which is resulted from synthesis has high enough value and is far from the SNI standard range. The high viscosity value is due to the imperfect synthesis process and many free fatty acids with long carbon chains in the biodiesel produced. The longer the carbon chain is, the more hydrogen bonds and the Van der Waals force to increase the solution's viscosity. Using a $5 \%$ catalyst, which is expected to have a more active sites, can cause an imbalance of reactant adsorption and product desorption. Thus, not all triglycerides in vegetable oils are converted into methyl esters but remain as triglycerides. The presence of glycerol in the sample can also be another cause of high-yield biodiesel viscosity. If the synthesized biodiesel wants to be used as diesel fuel, it must first be mixed with diesel to reduce its viscosity.

In a diesel engine, liquid fuel is sprayed into compressed air and atomized into small droplets near the nozzle's exit. Liquid fuel usually forms a cone-shaped spray at the nozzle's exit, and its viscosity affects the quality of the atomization, the size of the fuel droplets, and penetration (spread). High-viscosity fuel tends to form larger droplets at injection, which can cause poor fuel atomization during spraying, increase engine deposits, require more energy to pump fuel. High viscosity causes low combustion, increased exhaust fumes, and emissions. High viscosity also causes more problems in cold weather because viscosity increases with a decrease in temperature. Fuels with low viscosity may not provide good lubrication for fuel injection pumps, which results in leakage or increased wear (Knothe \& Gerpen, 2005; Soetaredjo et al., 2011).

\section{Conclusion}

The present study has opened a new route in applying bifunctional catalyst (GO-K-Clay) in biodiesel production. Natural kaolinite clay from Lubuk Minturun consists of $54 \%$ silica, 35\% alumina, and 7\% hematite, with the most dominant crystalline composition is kaolinite, quartz, and hematite. From the XRD data, it is also known that the modification of clay with $\mathrm{KOH}$ and $\mathrm{GO}$ does not significantly change the basic framework of clay minerals present in the sample. The analysis results using FTIR shows a change in intensity and shift in wavenumbers, indicating a cation exchange. Based on research that has been done, it can be concluded that graphene oxide (GO) is successfully synthesized using the Hummer method as evidenced by the presence of an XRD peak at $2 \theta=10^{\circ}$, which is the typical peak of GO. GO testing with FTIR also proves the synthesis of GO from graphite in the presence of epoxide, carboxyl, hydroxyl, and carbonyl functional groups that are usually found in GO. The hydrophilic hydroxyl groups on the GO-K-Clay catalyst surfaces plays a vital role in the transesterification of triglycerides in palm oil to FAME. Catalytic activity of GO-K-Clay catalyst performs better than the O-Clay, P-Clay, and KClay catalysts, with a yield of methyl esters reaching $58 \%$. Whereas O-Clay, P-Clay, and K-Clay catalysts have only a yield of $0.8 \%$ : $0.6 \%$ : and $0.4 \%$, respectively.

\section{Acknowledgments}

The authors would like to thank the LPPM of Andalas University for providing financial support in carrying out this work through research contract no. T/60/UN.16.17/PP.IS-KRP2GB/LPPM/2019.

\section{References}

Ali, B., Yusup, S., Quitain, A. T., Alnarabiji, M. S., Kamil, R. N. M., \& Kida, T. (2018). Synthesis of novel graphene oxide/bentonite bi-functional heterogeneous catalyst for one-pot esterification and transesterification reactions. Energy Conversion and Management, 171(June), 18011812. https://doi.org/10.1016/j.enconman.2018.06.082

Alves, H. J., da Rocha, A. M., Monteiro, M. R., Moretti, C., Cabrelon, M. D., Schwengber, C. A., \& Milinsk, M. C. (2014). Treatment of clay with KF: New solid catalyst for biodiesel production. Applied Clay Science, 91-92, 98-104. https://doi.org/10.1016/j.clay.2014.02.004

Amri, A., Ekawati, L., Herman, S., Yenti, S. R., Zultiniar, Aziz, Y., Utami, S. P., \& Bahruddin. (2018). Properties enhancement of cassava starch based bioplastics with addition of graphene oxide. IOP Conference Series: Materials Science and Engineering, 345(1). https://doi.org/10.1088/1757-899X/345/1/012025

Bet-Moushoul, E., Farhadi, K., Mansourpanah, Y., Molaie, R., Forough, M., \& Nikbakht, A. M. (2016). Development of novel Ag/bauxite nanocomposite as a heterogeneous catalyst for biodiesel production. Renewable Energy, 92, 12-21. https://doi.org/10.1016/j.renene.2016.01.070

Cheng, J., Qiu, Y., Zhang, J., Huang, R., Yang, W., \& Fan, Z. (2017). Conversion of lipids from wet microalgae into biodiesel using sulfonated graphene oxide catalysts. Bioresource Technology, 244(May), 569-574. https://doi.org/10.1016/j.biortech.2017.07.142

Costanzo, P. M. (2001). Baseline studies of the clay minerals society source clays: Introduction. Clays and Clay Minerals, 49(5), 372-373. https://doi.org/10.1346/CCMN.2001.0490502

D'Souza, R., Vats, T., Chattree, A., \& Siril, P. F. (2018). Graphene supported magnetically separable solid acid catalyst for the single step conversion of waste cooking oil to biodiesel. Renewable Energy, 126, 1064-1073. https://doi.org/10.1016/j.renene.2018.04.035

Dang, T. H., Chen, B. H., \& Lee, D. J. (2013). Application of kaolin-based catalysts in biodiesel production via transesterification of vegetable oils in excess methanol. Bioresource Technology, 145, 175-181. https://doi.org/10.1016/j.biortech.2012.12.024

Fadhil, A. B., Al-Tikrity, E. T. B., \& Khalaf, A. M. (2018). 
Transesterification of non-edible oils over potassium acetate impregnated $\mathrm{CaO}$ solid base catalyst. Fuel, 234(June), 81-93. https://doi.org/10.1016/j.fuel.2018.06.121

Gaidukevic, J., Barkauskas, J., Malaika, A., Rechnia-Goracy, P., Mozdzyńska, A., Jasulaitiene, V., \& Kozlowski, M. (2018). Modified graphene-based materials as effective catalysts for transesterification of rapeseed oil to biodiesel fuel. Cuihua Xuebao/Chinese Journal of Catalysis, 39(10), 1633-1645. https://doi.org/10.1016/S1872-2067(18)63087-6

Gao, W. (2012). Graphite Oxide:Structure,Reduction and Applications. March 2012, 6-10.

Ghiaci, M., Aghabarari, B., \& Gil, A. (2011). Production of biodiesel by esterification of natural fatty acids over modified organoclay catalysts. Fuel, 90(11), 3382-3389. https://doi.org/10.1016/j.fuel.2011.04.008

Hidayat, A., Setiadji, S., \& Hadisantoso, E. P. (2019). Sintesis Oksida Grafena Tereduksi (rGO) dari Arang Tempurung Kelapa (Cocos nucifera). Al-Kimiya, 5(2), 68-73. https://doi.org/10.15575/ak.v5i2.3810

Johansen, I. (2014). Wet Chemical Synthesis of Graphene for Battery Applications. June.

Knothe, G., \& Gerpen, J. Van. (2005). The Biodiesel Handbook. In The Biodiesel Handbook. https://doi.org/10.1201/9781439822357

Kusrini, E. (2018). Synthesis and Characterization of Graphite Oxide, Graphene Oxide and Reduced Graphene Oxide from Graphite Waste using Modified Hummers's Method and Zinc as Reducing Agent. International Journal of Technology, 10(6)(1), 1093-1104.

Loy, A. C. M., Quitain, A. T., Lam, M. K., Yusup, S., Sasaki, M., \& Kida, T. (2019). Development of high microwaveabsorptive bifunctional graphene oxide-based catalyst for biodiesel production. Energy Conversion and Management, 180(September 2018), 1013-1025. https://doi.org/10.1016/j.enconman.2018.11.043

Narayanan, D. P., Sankaran, S., \& Narayanan, B. N. (2019). Novel rice husk ash - reduced graphene oxide nanocomposite catalysts for solvent free Biginelli reaction with a statistical approach for the optimization of reaction parameters. Materials Chemistry and Physics, 222(September 2018), 63-74. https://doi.org/10.1016/j.matchemphys.2018.09.078

Olutoye, M. A., \& Hameed, B. H. (2013). A highly active claybased catalyst for the synthesis of fatty acid methyl ester from waste cooking palm oil. Applied Catalysis A: General, 450, 57-62. https://doi.org/10.1016/j.apcata.2012.09.049

Olutoye, M. A., Wong, S. W., Chin, L. H., Amani, H., Asif, M., \& Hameed, B. H. (2016). Synthesis of fatty acid methyl esters via the transesterification of waste cooking oil by methanol with a barium-modified montmorillonite K10 catalyst. Renewable Energy, 86, 392-398. https://doi.org/10.1016/j.renene.2015.08.016

Rabie, A. M., Mohammed, E. A., \& Negm, N. A. (2018). Feasibility of modified bentonite as acidic heterogeneous catalyst in low temperature catalytic cracking process of biofuel production from nonedible vegetable oils. Journal of Molecular Liquids, 254(2018), 260-266. https://doi.org/10.1016/j.molliq.2018.01.110

Rafitasari, Y., Suhendar, H., Imani, N., Luciana, F., Radean, H., \& Santoso, I. (2016). Sintesis Graphene Oxide Dan Reduced Graphene Oxide. October, SNF2016-MPS-95-SNF2016MPS-98. https://doi.org/10.21009/0305020218

Rahayu, S. (2017). Prosiding Seminar Nasional Kimia UNY 2017
Sinergi Penelitian dan Pembelajaran untuk Mendukung Pengembangan Literasi Kimia pada Era Global Ruang Seminar FMIPA UNY, 14 Oktober 2017. Prosiding Seminar Nasional Kimia UNY 2017, 2009, 319-324.

Rahmani Vahid, B., \& Haghighi, M. (2017). Biodiesel production from sunflower oil over $\mathrm{MgO} / \mathrm{MgAl} 2 \mathrm{O}$ 4nanocatalyst: Effect of fuel type on catalyst nanostructure and performance. Energy Conversion and Management, 134, 290-300. https://doi.org/10.1016/j.enconman.2016.12.048

Refaat, A. A. (2009). Correlation between the chemical structure of biodiesel and its physical properties. International Journal of Environmental Science and Technology, 6(4), 677-694. https://doi.org/10.1007/BF03326109

Ruhe, C. H. W. (1973). Statistical Review. JAMA: The Journal of the American Medical Association, 225(3), 299-306. https://doi.org/10.1001/jama.1973.03220300055017

Schroeder, P. (2002). Infrared spectroscopy in clay science. Teaching Clay Science, 11(January 2002), 181-206.

Shao, G., Lu, Y., Wu, F., Yang, C., Zeng, F., \& Wu, Q. (2012). Graphene oxide: The mechanisms of oxidation and exfoliation. Journal of Materials Science, 47(10), 44004409. https://doi.org/10.1007/s10853-012-6294-5

Simarmata, F. H. W. (2018). Sintesis Grafena Berlapis Nano Dari Grafit Menggunakan Reduktor Magnesium.

Soetaredjo, F. E., Ayucitra, A., Ismadji, S., \& Maukar, A. L. (2011). KOH/bentonite catalysts for transesterification of palm oil to biodiesel. Applied Clay Science, 53(2), 341-346. https://doi.org/10.1016/j.clay.2010.12.018

Suryaputra, W., Winata, I., Indraswati, N., \& Ismadji, S. (2013). Waste capiz (Amusium cristatum) shell as a new heterogeneous catalyst for biodiesel production. Renewable Energy, 50, 795-799. https://doi.org/10.1016/j.renene.2012.08.060

Syukri, S., Septioga, K., Arief, S., Putri, Y. E., Efdi, M., \& Septiani, U. (2020). Natural Clay of Pasaman Barat Enriched by $\mathrm{CaO}$ of Chicken Eggshells as Catalyst for Biodiesel Production. 15(3), 662-673. https://doi.org/10.9767/bcrec.15.3.8097.662-673

Talyzin, A. V, Solozhenko, V. L., Kurakevych, O. O., Szabó, T., Døkuny, I., Kurnosov, A., \& Dmitriev, V. (2008). Colossal Pressure-Induced Lattice Expansion of Graphite Oxide in the Presence of Water **. 8268-8271. https://doi.org/10.1002/anie.200802860

Taufantri, Y., Irdhawati, I., \& Asih, I. A. R. A. (2016). Sintesis dan Karakterisasi Grafena dengan Metode Reduksi Grafit Oksida Menggunakan Pereduksi Zn. Jurnal Kimia VALENSI, $2(1), \quad 17-23$. https://doi.org/10.15408/jkv.v2i1.2233

Thomas, R. E. (2010). High temperature processing of kaolinitic materials. The University of Birmingham Doctoral Thesis, February, 4. https://core.ac.uk/download/pdf/33528378.pdf

Waktu, P., Struktur, T., Pradesar, Y., Teknik, J., \& Industri, F. T. (2013). Pengaruh Waktu Ultrasonikasi dan Waktu Tahan Proses Hydrothermal Terhadap Struktur dan Sifat Listrik Material Graphene. 2(1).

Xie, W., \& Li, H. (2006). Alumina-supported potassium iodide as a heterogeneous catalyst for biodiesel production from soybean oil. Journal of Molecular Catalysis A: Chemical, 255(1-2), https://doi.org/10.1016/j.molcata.2006.03.061

Zhang, Z. Y., Huang, L., Liu, F., Wang, M. K., Fu, Q. L., \& Zhu, J. (2016). Characteristics of clay minerals in soil particles of two Alfisols in China. Applied Clay Science, 120, 51-60 https://doi.org/10.1016/j.clay.2015.11.018 